UDC 343.37:35.072+341.172+352.07

DOI https://doi.org/10.32838/1606-3716/2020.4/04

Nediukha M.P.

V.I. Vernadsky Taurida National University

Podolyaka A.M.

Interregional Academy of Personnel Management

Podolyaka S.A.

Interregional Academy of Personnel Management

\title{
POLITICAL CORRUPTION AS A SOCIAL AND LEGAL PHENOMENON: POLITICAL AND LEGAL MODELS OF COUNTERACTION (ARTICLE 2)
}

The essence and mechanism of identification, prevention and counteraction to political corruption are clarified, allows to consider the latter as a dysfunction of public administration, a sign and result of bureaucratic rebirth of public authorities and local self-government. The threats of bureaucratic and corrupt deformation of democratic governance and related risks and dangers of the sovereign development of the Ukrainian state are emphasized.

Max Weber's theory of rational management is considered as a theoretical and methodological basis for the institutional support of anti-corruption in accordance with the living conditions of Ukrainian society in its basic functions: a) adaptation; b) integration; c) goal achievement; d) structure reproduction and relief. It is proved that these create the necessary conditions to ensure the unity of political will and practical action of public authorities and local governments in accordance with the needs of "network organization" of social and political space of the country, trust and respect, forming partnerships between government and society as a source of overcoming the bureaucratic component of corruption offenses.

The institutional model of counteracting political corruption as a theoretical and legal basis for developing innovative strategies to respond to the challenges and threats of corruption in public authorities and local governments is substantiated.

The essence of the institutional model is that, first, the fight against corruption is embedded in the management process in accordance with the criteria of integrity of the administration, substantive, organizational and disciplinary content of the rule of law; secondly, the potential for combating corruption allows to implement the rule of law in the activities of any body of state power and local self-government, where the priority is the task of effective governance in the mode of accessibility and openness on line; thirdly, the institutional model of anti-corruption is substantiated as a fundamental basis for the development of innovative models of deterrent corruption in the activities of public authorities and local governments.

The substantive and functional characteristics of the innovative model of deterring corruption in the prosecutor's office of Ukraine as a kind of institutional model are presented.

Key words: corruption, political corruption, bureaucracy, bureaucracy, institutional model of counteraction to political corruption in state and local self-government bodies, innovative model of restraining counteraction to political corruption in prosecutors of Ukraine.

Combating political corruption as a social evil in its significance, ability to find adequate answers to the challenges, risks and dangers of modern statehood should be seen as a national field of interaction and confrontation of diverse political forces, financial and industrial groups, civil servants, government and society, individual citizens. The defining means of this counteraction is, of course, the political will underlying the state anti-corruption policy, reforming law enforcement agencies and the judiciary, forming political actors that would be guided by the ideology of national development, strategically defined priorities of social change, sustainable development of Ukraine and civilized standards of standard and quality of life. This means that the activities of the prosecutor's office should be reoriented from the realization of the state interest to the legal protection of national interests as the embodiment 
of the full realization of human and civil rights and freedoms in a safe social political and legal space which is called "Ukraine".

It is hardly expedient to connect the essence and scale of the spread of political corruption with the mentality of the people, their social conditions, inherent in one or another stage of transformational changes in society, and even more so the historical periods of struggle for their own statehood.

The state-building potential of the Ukrainian people is clearly expressed anti-corruption nature. The constitutional thesis "the Ukrainian people are the source of power" does not mean the attributive corruption of the government, as well as the invincibility of this negative socio-legal phenomenon.

Responding to the challenges of today, the Ukrainian people, as the source and bearer of power, must propose appropriate political and legal mechanisms for public control of power, its democratic implementation, preventing states of bureaucratic rebirth, and so on. The "price" of the civil service and local self-government bodies should be determined not by prestige, privileges or, say, salaries of officials, etc., but exclusively by the social results of their activities, the degree of involvement in state-building processes, and the establishment of civilized social standards. Ukraine's new capabilities are also linked to a fair trial and legal protection for Ukrainian citizens.

The formation of modern bureaucracy the administrative apparatus of public authorities and local government requires adaptation of its tasks in accordance with indicators of modernization of the country [28], sources of socio-political tension [29], causes of conflict [30], effective national security management [31, p. 28], based on the analysis of the defining indicators of direct and indirect threats to human security [32], his rights and freedoms [33], etc.

Political corruption is a socio-legal phenomenon caused by bureaucratic distortions of the top management and consists in the exchange of information, services, powers and resources (financial, logistical, human, organizational, etc.) for personal gain. This can transform or, at least, deform the administrative apparatus of public authorities and local self-government into a closed, selfregulatory, uncontrolled body, where corruption and bureaucratic relations, not regulated by law or morality, are decisive.

The challenges associated with the normalization of these relations are to find satisfactory answers to the threats of: a) excessive public administration; b) incomplete public administration reform; c) limited "transparency" of civil control; d) weaknesses of the state personnel policy; e) lack of ideologically and politically oriented strategic priorities for the formation of the rule of law and civil society in Ukraine; f) limited resources for the establishment of civilized standards of living standards and quality of life, etc. Accordingly, it is necessary to combat corruption not only as a sociolegal phenomenon that is generated, stimulated and provided by bureaucracy as a distorted system of government, but also it is important to clarify the objective and subjective conditions, factors and reasons that contribute to the deformation of management staff of state authorities and local governments, senior officials, politicians, etc. The traditional rationalization of management "vertically" should be complemented by modern counter-flows of civic activity "horizontally", aimed at finding satisfactory answers to today's challenges - legislative, executive, information, judicial, security, technology and more.

The essence of political corruption is directly related to the selfish corporate and personal interests of politicians, senior and middle managers of public authorities and local governments. Its peculiar source is the internal contradiction of the administration as the unity of two opposing parties - legitimacy, professionalism, high executive discipline, organizational and structural perfection, usually regulated by law, on the one hand, and isolation from life, public demands, basic needs of citizens, formalism, protectionism and meticulousness, on the other hand.

Subordination of the state will to private or corporate interest forms a rigid, cynical latent-corrupt system of government with its inevitable merging of power and business, the dominance of corrupt bureaucratic practices that parasitize on democratic values, neglect civilization standards of quality and quality of life, legal and social norms unltermine foundations of the moral and political unity of society, demoralizing and decomposing it from within. Corrupt government with its bureaucratic arbitrariness, formal and clerical reports, cynicism, double standards, its own subculture poses a major threat to the democratic state, human and civil rights and freedoms, becomes a brake on the process of modernization change.

It is obvious that in the conditions of the modernization of the Ukrainian state and society the restriction of the arbitrariness of the bureaucracy of the bodies of state power and local self-government by means, first of all, of identification, prevention and counteraction to political corruption becomes of decisive importance. 
The theoretical and methodological basis for preventing, at least, minimizing the consequences of bureaucratic degeneration of the administration can be considered the conceptual provisions of a number of modern management theories - "service state", "public governance", "e-government", "network administration", "new government", etc. aimed at regulating the mechanisms of decentralization of power, interaction between the state and civil society institutions, compromise decision-making, etc.

Substantiation of the institutional model of combating political corruption, as noted in the previous article, allows to determine the basic principles of theoretical and conceptual and regulatory support for the implementation of an innovative model of identification, prevention and combating corruption in the prosecutor's office of Ukraine.

The innovative model of deterrent anti-corruption strategy - based on the activity of the Prosecutor's Office ofUkraine as a law enforcementagency-is based on a number of theoretical and conceptual provisions, including: a) the thesis of German sociologist Max Weber on bureaucracy as a rational form of government and its evolution, which develop according to the scheme: bureaucracy - the state of bureaucracy as a possible threat of rebirth of the administrative apparatus, including on the basis of corruption [20]; b) understanding of political corruption as the main threat to the sovereign development of Ukraine; c) normative-legal substantiation of the innovative model of deterring corruption, based, according to Weber, on the attributive unity of the administration and threats of corruption in the absence of adequate safeguards, which are properly justified legal norms and "moral purity" of public officials and local selfgovernment, as well as public control of civil society institutions over the results of their activities.

The innovative model of anti-corruption is ensured by the activity of the prosecutor's office as a party to the public prosecution, as well as its status as a coordinating and supervisory body for the activities of other law enforcement agencies, except the judiciary, and operational and investigative activities.

The main functions of anti-corruption in the prosecutor's office of Ukraine are: a) identification function, the essence of which is to establish the facts of corruption, as well as the conditions and causes that led to the act of corruption; b) law enforcement function - investigation of corruption offenses and crimes; c) the coordination function is to ensure the coordinated activities of pre-trial investigation bodies by the prosecutor's office, as well as to coordinate the activities of other anti-corruption actors; d) supervisory function - supervision by the prosecutor's office over the legality of operational and investigative activities and pre-trial investigation carried out by the prosecutor's office over the pre-trial investigation bodies [5, p. 185-191, 196-200].

A special role in determining the content of the innovative model of identification, prevention and counteraction of corruption is given to the subjects of counteraction to corruption in the prosecutor's office of Ukraine, which can be classified on various grounds, in particular: 1) by the nature of administrative and legal status; divisions and officials; 2) on the grounds of structural and hierarchical affiliation of the subjects of anti-corruption in the prosecutor's office: a) internal subjects of anti-corruption, which are structural elements of the system of the prosecutor's office; b) external anti-corruption actors that fight corruption in the prosecutor's office, without being part of its system.

Such bodies in the anti-corruption mechanism in the prosecutor's office are, as is well known, NABU and NAPC, which provide specialized anticorruption activities: NABU conducts pre-trial investigation and operational and investigative activities, while NAPC is the body of administration of the national mechanism for combating corruption, whose powers also extend to the activities of the prosecutor's office of Ukraine; 3 ) by functional purpose in the structure of the political and legal mechanism of anti-corruption: a) bodies that adopt the state anti-corruption policy (Verkhovna Rada of Ukraine) and implement it at the national level (NAPC); b) bodies with coordination functions and powers in the field of anti-corruption (Cabinet of Ministers of Ukraine, President of Ukraine, local bodies of general competence, etc.); c) bodies carrying out direct law enforcement activities in the implementation of proceedings on corruption administrative offenses and crimes (NABU, SAP, prosecutors as officials who draw up a report on corruption offenses or public prosecutors, the Security Service of Ukraine, the National Police of Ukraine, SBI); d) prosecutors who oppose corruption as heads of prosecutor's offices or their subdivisions; e) bodies and persons contributing to the fight against corruption in the prosecutor's office; f) judicial authorities; 4) by level of specialization: a) bodies and persons whose activity in combating corruption is the main area of activity (NABU; SAP; NAPC); b) law enforcement agencies for which the fight against corruption is part of the general law enforcement activity (SBU; National Police of Ukraine; prosecution units; SBI); c) bodies and persons for whom anti-corruption is not the main 
field of activity, but is carried out in accordance with the administrative and legal status (administrative positions in the prosecutor's office, if the activity is not carried out in the status of law enforcement, Cabinet of Ministers, Verkhovna Rada of Ukraine, President of Ukraine) etc. [5, p. 146-222, 395-397].

The effectiveness of the legal mechanism for identifying, preventing and combating corruption in the prosecutor's office is ensured by the structural unity of its components, in particular: a) the certainty of the subjects of anti-corruption; b) the possibility of its deployment as a process of extrapolation of the requirements of the rule of law on legal relations with the participation of prosecutors; c) the need to adopt acts, the content of which is to combat corruption in the activities of public authorities, as well as the bodies of united territorial communities at different stages and levels of their activities; d) bringing participants of legal relations - both subordinate and coordinated - to disciplinary, administrative and criminal liability.

Instead, at the national level, the effectiveness of anti-corruption is a public response to the "measure" of successful transformation of the traditional type of public administration into its modern counterpart governance with such basic characteristics as openness, accessibility, transparency, public control over performance, standards and quality of life etc.

Accordingly, it seems appropriate to amend the domestic legislation taking into account the competence of the bodies that form the hierarchy of law enforcement agencies as anti-corruption entities, in particular, in terms of specifying tasks related to: a) combating criminal corruption offenses committed by senior officials; authorized to perform the functions of the state or local self-government, and which pose a threat to national security (Article 1 of the Law of Ukraine "On the National AntiCorruption Bureau of Ukraine") [34]; supervision, support of public prosecution and representation of interests in cases related to anti-corruption (Article 8-1 of the Law of Ukraine "On the Prosecutor's Office") [35]. They also need to clarify the tasks related to the detection, prevention and cessation of corruption offenses, participation in the detection of corruption offenses, search for the perpetrators, in the manner prescribed by criminal procedure law.

In terms of implementing measures to implement an innovative model of deterring corruption, it seems appropriate to adopt the Regulation "On monitoring the media and social networks to identify corruption risks", which determines the procedure in case of detection of certain information about possible corruption in the prosecutor's office or pre-trial investigations, the activities of which are coordinated by the bodies of the Prosecutor's Office of Ukraine, theresponsible persons of the bodies of the Prosecutor's Office of Ukraine based on the results of responding to corruption and the procedure for prosecuting inaction in this area. At the same time, it is also necessary to determine the subjects of monitoring at the central and regional levels [5, p. 406].

The tasks of effective functioning of these models of anti-corruption - institutional and innovative - make it necessary to implement some legislative initiatives, in particular: a) adoption of the Law of Ukraine "On the Supreme AntiCorruption Court" in accordance with the registered bill № 7440 of December 22, 2017 and “On State AntiCorruption Policy in Ukraine (Anti-Corruption Strategy) for 2018-2020" on the basis of a bill proposed by the NAPC; b) supplementing the list of functions of the SAP, defined in Part 5 of Art. 8 of the Law of Ukraine "On the Prosecutor's Office" with the wording according to which the SAP "organizes the fight against corruption in the prosecutor's office of Ukraine".

Integrity, as a condition of impeccable professional reputation, should be the basis of the legislative process and, accordingly, it should be considered as a determining criterion for anti-corruption behavior of officials of the Prosecutor's Office of Ukraine, public authorities and local governments.

According to the above, it is important to adopt a law regulating lobbying in Ukraine, which would allow lobbyists to get out of the shadow of illegal lobbying. At the same time, the actions of the legislator aimed at developing the content of the relevant articles of the Constitution and minimizing the by-laws of this type of activity, which would give the law a basic, framework and regulatory character, are considered urgent. At the same time, it is important to clearly write amendments to the law, which would provide for the definition of lobbying as a system of legislative support for coordinated actions of entities to provide relevant services, legal mechanism for paying lobbyists, remuneration, administrative and criminal liability.

Adoption of the law on lobbying in Ukraine would significantly intensify the dialogue of civil society, its individual, most active centers-NGOs, interest groups, small and medium enterprises, individual citizens with the state in the part that is associated primarily with ensuring transparency of public authorities and local self-government, and thus a significant restriction on the corruption of government at various levels of its structural hierarchy. 
Peculiarities ofthelegalmechanismofidentification, prevention and counteraction to corruption in the prosecutor's offices of Ukraine are shown in its subordination to the tasks of systemic counteraction to corruption, consideration of the latter as a dysfunction of the prosecutor's office. This determines: a) the legal status of the prosecutor's office as an independent, autonomous body; b) understanding of the essence of procedural independence of prosecutors, the legal status of participants in the fight against corruption; c) substantive, structural and functional unity of the components of the mechanism of identification, prevention and counteraction of corruption; d) acts of implementation of the rule of law in its compliance with legal facts; e) means of ensuring political and legal coercion and bringing to justice.

The organizational component of the fight against corruption in the prosecutor's office is formed by: a) the implementation of proceedings to bring to justice for corruption offenses, including the preparation of a protocol; b) carrying out disciplinary proceedings on corruption offenses; c) transfer of information on corruption offenses to the competent authorities; d) removal or dismissal for corruption offenses; e) representation in court by way of criminal proceedings or proceedings on an administrative offense; f) adoption of normative legal acts on counteraction to corruption in prosecutor's offices; h) anti-corruption examination of normative legal acts; j) adoption of acts on the implementation of organizational and legal measures for the implementation of state anti-corruption policy; $\mathrm{k}$ ) anti-corruption inspection when hiring and promotion; $\mathrm{m}$ ) combating corruption in the process of coordinating the activities of pre-trial investigation bodies, etc. [5, p. 94-151, 252-275, 392].

The appointment of disciplinary liability as part of an innovative model of combating corruption is seen in its dominant direction, ensuring mostly conscientious performance of official duties, providing for liability not only for specific illegal actions, but also for improper performance of powers, and in some cases - and for a negative result of official activity. In this sense, it can be argued that disciplinary liability not only complements other types of liability, especially administrative and criminal, but also forms the initial, basic level of anti-corruption, thereby motivating the subjects of legal action to lawful, ethically correct conduct, integrity.

Systematic interaction of the components of the innovative model of anti-corruption in the prosecutor's office is provided by political, legal and moral-ethical means of minimizing the impact of daily activities of the administration on the performance of official duties, finding satisfactory answers to threats of corruption by government officials and local self-government in accordance with the theoretical and methodological guidelines of modern state management, the tasks of transforming the state into a "service", etc. This presupposes the decentralization of power by delegating powers to the appropriate level of their proper implementation, the formation of a system of modern government as a dynamic system of interaction between government and people, state and citizens on the basis of the rule of law and personal responsibility.

The model vision of combating corruption - institutional and innovative - suggests theneed tosupplementtheestablishedmeans of combating corruption with the concept of "identification", which embodies a certain sequence of the process of determining the conformity of a social phenomenon to certain essential and functional features as qualification criteria [36].

Thus, in particular, in our case, the term "identification" implies clarification of: a) the powers, status and nature of the subject of public authority or local government, the nature and nature of the act of compliance with certain legal and social norms and requirements integrity, openness, transparency, international indicators of "good" governance, etc.; b) determination of the purpose of illegal activity; c) finding out the damage, possible losses - human, property, financial, environmental, etc. At the same time, the means of identification of corruption offenses also include preventive actions, which are associated with the search for satisfactory moral, ethical and legal answers to real and potential corruption challenges and threats.

Constitutional and legal support for the identification, prevention and counteraction of corruption in the prosecutor's office should be understood as a system of public measures aimed at implementing state anti-corruption policy, which includes legal, organizational, disciplinary, personnel and other means carried out in the process of the above bodies. in terms of minimizing corruption risks in accordance with the requirements of the law, challenges and threats to the sovereign development of Ukraine. This also involves eliminating the negative consequences that have arisen as a result of direct or indirect effects of corruption / inaction. Accordingly, the causes of political corruption, the conditions and sources of its emergence and spread, its essence must be organically linked to the legal mechanism of its identification, prevention and counteraction as a political and legal phenomenon. 
At the same time, the main areas of combating corruption are considered to be: detection, investigation, consideration of the facts of corruption, ensuring the statutory liability for corruption offenses; improvement of anti-corruption legislation; restoration of legal rights and interests of individuals and legal entities, elimination of the consequences of corruption.

Instead, political and legal means, mechanisms and directions of corruption prevention include: a) elimination, neutralization and mitigation of corruption factors; b) obstruction of the implementation of the illegal intention of the official to implement the intent to commit a corruption offense; c) cessation of corrupt activities that have already begun, in order to prevent the occurrence of illegal (criminal) results or the growth of corruption into a more socially dangerous [37, p. 11-13].

They also proved their effectiveness as a means of preventing political corruption by applying qualitative research by studying public opinion, social media content, monitoring media reports, expert research, etc., and quantitative research, the essence of which is known to be using statistical methods of processing the received information, facts and messages [38].

The degree of counteraction of political corruption largely determines the effectiveness of public authorities and local governments as subjects of the process of social change, modernization of Ukrainian society, is associated with the formation of the administration in accordance with the latest challenges and dangers of Ukraine's sovereign development.

Conclusions. The main direction of social and legal counteraction to corruption is, of course, the formation of a political system of institutional type with a clear definition of constitutional and legal status, functions and competencies of public authorities and local government, place, functions and appointment of political parties as a means of delegating and realizing civil society. subordination of power to the task of implementing the basic functions of society - achieving goals, adapting, integrating, reproducing the structure and relieving tension.

Accordingly, the purpose of law should be seen in the regulation of social interaction, where human rights and freedoms, civilized standards of living standards and quality, the formation of civil society institutions, the institutionalization of public authorities and local self-government are decisive. A kind of indicator of the completion of the processes of institutionalization of the latter and the degree of implementation of social justice should be the reform of the judiciary in accordance with the requirements of the rule of law.

The above gives grounds to define the essence of the concept of "political corruption" as illegitimate use by senior officials of public authorities and local governments of powers, funds and resources, opportunities to influence as illegal means of personal or corporate gain (position, benefits, property) and illicit enrichment.

The innovative model of combating corruption in the prosecutor's office is understood as a hierarchical system that provides legal, social, organizational and disciplinary components that determine its public-functional nature, status and purpose.

The above model can be defined as deterrent, because, firstly, corruption, as international experience shows, cannot be defeated and, secondly, the fight against corruption, its identification and prevention must be embedded in the daily activities of the administration. Substantiated theoretical and normative-legal provisions can be extended to any form of rational organization of labor and management in public authorities and local self-government, while characterizing the level of development of civil society institutions.

The public-functional nature, status and purpose of the innovative model of deterring corruption in the prosecutor's office with its components - legal, social, organizational and disciplinary - are the timely identification of challenges and threats associated with political corruption, moral and ethical and legal qualifications facts of corruption, prevention of their occurrence by taking into account the peculiarities of the management apparatus - political, social, organizational, personnel, etc. in accordance with the living conditions of society, its current state, prospects for growth in terms of capacity for mobilization, social change, stress relief, adaptation and integration. This also involves eliminating the negative consequences of corrupt practices, including by restoring the lost reputation, based on the latest conceptual understanding of the functional nature of the prosecutor's office.

The effectiveness of the innovative model of anticorruption in the prosecutor's office of Ukraine is determined by the defining trends of law enforcement, which, in particular, determines: a) regulatory support for the functioning of the administration as a hierarchically structured system in accordance with the requirements of "good" governance, public control "on-line", etc; b) unconditional integrity 
of employees of the Prosecutor's Office of Ukraine in terms of compliance of their official and personal conduct with established moral and ethical requirements and standards; c) shifting the emphasis from the punitive to the regulatory function of administrative legislation with the subsequent achievement of their parity; d) substantive, functional and structural improvement of the activity of the bodies of the Prosecutor's Office of Ukraine by adaptation to the legal norms of the Member States of the European Union; e) promoting the formation and development of certain institutions aimed at combating corruption in the prosecutor's office - the institute of declaration, the institute of anti-corruption inspections, the institute of covert management of corruption risks, etc; f) monitoring of the media as a source of corrupt information reports; h) compliance of the results of the professional activity of the management staff of the prosecutor's office with the challenges and threats to the sovereign development of Ukraine; j) approval of the coordinating role of the prosecutor's office as a determining link in the formation of systemforming links between law enforcement agencies, as well as the avoidance of duplication of powers and responsibilities; k) making appropriate changes to the administrative-tort and administrative- procedural legislation, adoption of the updated Code of Ukraine on Administrative Offenses and the Code of Administrative Procedures.

The introduction of an innovative model of identification, prevention and counteraction to corruption in the prosecutor's office involves the deployment of each of its components as a systemic whole-legal, public, social, organizational and disciplinary, which, as a means of forming institutional anti-corruption principles, generate a new quality it cannot be reduced to any of its components, manifesting itself simultaneously in each of them.

Thismeans that theabovemodelcanbeimplemented by:a)formation of systemic counteraction to corruption as a unity of legal, social, public, organizational and disciplinary means of activity of the Prosecutor's Office of Ukraine, its separate structural subdivisions operating within the law enforcement body; b) ensuring social orientation and public control over the activities of the prosecutor's office; c) priority of legal and organizational-public support for the implementation of anti-corruption programs; d) determination of the main legal, organizational and administrative means of combating corruption, as well as standardization of anti-corruption responsibility of prosecutors in accordance with the institutional requirements of governance.

\section{References:}

1. Moers L. Growth empirics with institutional measures and its application to transition countries: A survey. Working paper. Tinbergen Institute, University of Amsterdam, 1999.

2. Bajpai Kanti. Humain security: Concept and Measurement. Kroc Institut Occasional. Paper № 19. August 2000.

3. European Commission Check-list for Root Causes of Conflict. URL: http://ec.europa.eu/external_relations/cfsp/cpcm/cp/list.htm.

4. Недюха М.П., Федорін М.П. Деякі правові аспекти управління системою забезпечення національної безпеки України. Вісник Національної Академії прокуратури України. 2010. № 2. С. 24-29.

5. Economic Governance Programme. UNDP, Bratislava RSC. January 2003.

6. Gastil R. Freedom in the World: Political Rights and Civil Liberties. New York: Freedom House, 1989.

7. Про Національне антикорупційне бюро України: Закон України від 14.10.2014 р. № 1698-VII. Bidoмості Верховної Ради. 2014. № 47. Ст. 2051.

8. Про прокуратуру. Закон України від 14.10.2014 р. № 1697-VII. Відомості Верховної Ради (ВВР). 2015. № 2-3. Ст.12.

9. Великий тлумачний словник сучасної української мови / уклад. і голов. ред. В.Т. Бусел. Київ ; Ірпінь: ВТФ Перун, 2009. 1736 с.

10. Мельник М.І. Кримінологічні та кримінально-правові проблеми протидії корупції : автореф. дис. ... докт. юрид. наук : 12.00.08 / Національна академія внутрішніх справ України. Київ : 2002.28 с.

11. Johnson G., Scholes K. Exploring Corporate Strategy. Pearson Education LtD: FT Prentice Hall. 2002. 1082 p.

\section{Недюха М.П., Подоляка А.М., Подоляка С.А. ПОЛІТИЧНА КОРУПЦІЯ ЯК СОЦІАЛЬНО-ПРАВОВЕ ЯВИЩЕ: ПОЛІТИКО-ПРАВОВІ МОДЕЛІ ПРОТИДІЇ}

3'ясовано сутність і запропоновано механізм ідентифікації, запобігання та протидії політичній корупиії, який дозволяє розглядати останню як дисфункцію державного управління, ознаку і результат бюрократичного переродження органів державної влади та місчевого самоврядування. Наголошено 
на загрозах бюрократично-корупиійної деформаиії демократичного врядування та пов'язаних із ним ризиків і небезпек суверенного розвитку української держави.

Теорія раціональної організації управління Макса Вебера розглянута як теоретико-методологічна підвалина інституційного забезпечення протидї корупиії відповідно до умов життєдіяльності украӥнського суспільства за базовими його функціями: а) адаптаиії; б) інтеграції; в) иііледосягання; 2) відтворення структури та зняття напруги. Доведено, щео зазначеним створюються необхідні умови для забезпечення єдності політичної волі та практичної дії органів державної влади та місцевого самоврядування відповідно до потреб «мережевої організаиї̈ сочіального та політико-правового простору краӥни, утвердження довіри і поваги, формування партнерських відносин влади і суспільства як вихідних засобів подолання бюрократичної складової корупиійних правопорушень.

Обгрунтовано інституційну модель протидї політичній корупиії як теоретико-правову основу розроблення інноваиійних стратегій реагування на виклики та загрози корупиії в органах державної влади та місиевого самоврядування. Сутність інституційної моделі полягає в тому, що, по-перше, протидія корупиії закладена у процес управлінської діяльності відповідно до критеріїв доброчесності апарату управління, змістовного, організаиійного та дисциплінарного наповнення норми права; по-друге, потенціал протидії корупиії дозволяє реалізувати норму права в діяльності будь-якого органа державної влади та місиевого самоврядування, де пріоритетними є завдання ефективного врядування у режимі доступності та відкритості оп line; по-третє, інституційна модель протидї корупиї обгрунтована як засаднича підвалина розроблення інновачійних моделей стримуючої протидії корупџї в діяльності органів державної влади та місиевого самоврядування.

Викладено змістовні та функиіональні характеристики інноваиійної моделі стримуючої протидї корупиії в органах прокуратури Украӥни як різновиду інституційної моделі.

Ключові слова: корупчія, політична корупиія, бюрократія, бюрократизм, інституційна модель протидії політичній корупиї̈ в органах державної влади та місиевого самоврядування, інновачійна модель стримуючої протидї політичній корупщії в органах прокуратури Украӥни. 